\title{
ANALISIS PERSEPSI MASYARAKAT TERHADAP BANTUAN LANGSUNG TUNAI (BLT) PADA MASA PANDEMI COVID-19
}

\author{
${ }^{1}$ Rofiqoh Prepti Reptiana, ${ }^{2}$ Didik Widiantoro ${ }^{3}$ Wina Diana Sari, \\ ${ }^{4}$ Erika Desvianti, ${ }^{5}$ Ersaliya Arezah \\ 12345 Fakultas Psikologi, Universitas Islam Riau, Indonesia. \\ ${ }^{1}$ Corresponding Author: rofiqohpreptireptiana28@gmail.com
}

\begin{abstract}
Since the Corona Virus Disease-2019 (COVID-19) pandemic was officially declared to have entered Indonesia, in March 2020. This outbreak had an impact on the social and economic consequences of the Covid-19 pandemic which also affected the level of public welfare. This is due to the limitation of economic activity which at a macro level reduces economic growth and causes many people to lose their jobs, thereby potentially increasing the number of poor people. Based on this, the Government seeks to provide direct cash assistance for the community from the Village Fund or called BLT-Village Fund to reduce the burden on the poor due to the impact of Covid-19. BLT-Dana Desa is financial assistance sourced from the Village Fund and is intended for the poor and vulnerable who have difficulty meeting their daily needs, especially due to the Covid-19 outbreak. Village Fund Cash Direct Assistance (BLT-Village Fund) in Harapan Jaya Village, Central Bunguran District, Natuna Regency in 2020, for people who receive Village Fund Cash Direct Assistance (BLT) in Harapan Jaya Village, Bunguran Tengah District, Natuna Regency in 2020. quite a lot, namely with a total allocation of the number of people who receive as many as 225 Family Heads. The purpose of this study was to determine the perception of the recipient community towards the Direct Cash Assistance (BLT) program during the Covid-19 Pandemic in Harapan Jaya Village, Central Bunguran District, Natuna Regency. This research was conducted with descriptive qualitative methods, namely interviews and observations using purposive sampling technique. Data analysis technique using Milles and Huberman theory, namely redcing, presenting data, and concluding data. The results of this study indicate that the perceptions of the four subjects to feel the benefits of BLT are different.
\end{abstract}

Keywords: Perception, Bantuan Langsung Tunai (BLT), Covid-19

\begin{abstract}
ABSTRAK
Sejak wabah pandemi Corona Virus Disease-2019 (COVID-19) resmi dinyatakan masuk ke Indonesia, pada maret 2020. Wabah ini berdampak pada sosial dan ekonomi yang diakibatkan pandemi Covid-19 yang sekaligus berpengaruh bagi tingkat kesejahteraan masyarakat. Hal ini disebabkan adanya pembatasan kegiatan ekonomi yang secara makro menurunkan pertumbuhan ekonomi dan menyebabkan banyak orang kehilangan pekerjaan sehingga berpotensi meningkatkan jumlah masyarakat miskin. Berdasarkan hal itu Pemerintah berupaya memberikan bantuan langsung tunai bagi masyarakat yang bersumber dari Dana Desa atau disebut BLT-Dana Desa untuk mengurangi beban masyarakat miskin akibat dampak Covid-19. BLT- Dana Desa yaitu bantuan keuangan yang bersumber dari Dana Desa dan ditujukan bagi masyarakat miskin dan rentan yang kesulitan dalam memenuhi kebutuhan hidupnya sehari-hari terutama akibat wabah Covid-19. Bantuan Langsung Tunai Dana Desa (BLTDana Desa) di Desa Harapan Jaya Kecamatan Bunguran Tengah Kabupaten Natuna Tahun 2020, bagi masyarakat yang menerima Bantuan
\end{abstract}


Langsung Tunai (BLT) Dana Desa di Desa Harapan Jaya Kecamatan Bunguran Tengah Kabupaten Natuna Tahun 2020. cukup banyak yakni dengan jumlah alokasi jumlah jiwa yang menerima sebanyak 225 Kepala Keluarga. Tujuan penelitian ini yaitu untuk mengetahui persepsi masyarakat penerima terhadap program Bantuan Langsung Tunai (BLT) pada masa Pandemi Covid-19 di Desa Harapan Jaya Kecamatan Bunguran Tengah Kabupaten Natuna. Penelitian ini dilakukan dengan metode kualitatif deskriptif yaitu wawancara dan observasi dengan menggunakan teknik purposive sampling. Teknik analisis data menggunakan teori dari Miles dan Huberman yaitu Mereduksi Data, Menyajikan Data, dan Menyimpulkan Data. Hasil dari penelitian ini menunjukkan persepsi dari keempat Partisipan merasakan manfaat BLT yang berbeda-beda.

Kata Kunci: Persepsi, Manfaat Bantuan Langsung Tunai (BLT), Covid-19

\section{PENDAHULUAN}

Menurut sumber resmi dari bappenas.go.id, pada Maret 2020 pandemi Corona Virus Disease-2019 (Covid-19) resmi dinyatakan masuk ke Indonesia. Sejak saat itu, penyebarannya pun semakin meluas dan berkembang pesat di hampir seluruh provinsi yang ada di Indonesia. Wabah virus Covid-19 ini diperkirakan dapat menambah jumlah penduduk miskin yang ada di Indonesia, dibandingkan tahun sebelumnya. Wabah ini tentunya memberikan dampak buruk baik secara sosial maupun ekonomi yang sangat berpengaruh bagi kesejahteraan masyarakat. Hal ini dikarenakan adanya pembatasan ekonomi secara makro sehingga menimbulkan masyarakat ramai kehilangan pekerjaan dan sangat berpotensi akan menambah jumlah kemiskinan di Indonesia.

Sehingga untuk mencegah virus tersebut serta dalam upaya pencegahan berkembangnya mata rantai wabah pandemi, pemerintah baik pusat maupun daerah mengambil langkah-langkah untuk pencegahan.

Langkah-langkah pencegahan tersebut antara lain social distance (jarak sosial), pencegahan terhadap kegiatan di luar rumah, dan menutup tempat-tempat keramaian. Hal ini tentu sangat besar sekali pengaruhnya terhadap kehidupan perekonomian masyarakat secara umum. Dampak yang timbul adalah seperti pengurangan karyawan dengan PHK secara tiba-tiba, penurunan omset yang mengakibatkan bertambahnya jumlah pengangguran dan kemiskinan.

Pemerintah tentunya telah merencanakan berbagai kebijakankebijakan baru untuk menekan angka penyebaran dan penanganan virus Covid19 ini. Salah satunya dengan diterbitkannya Undang-Undang Nomor 2 Tahun 2020 tentang Penetapan Peraturan Pemerintah Pengganti Undang-Undang Nomor 1 Tahun 2020 tentang Kebijakan Keuangan Negara dan Stabilitas Sistem Keuangan untuk Penanganan Pandemi Corona Virus Disease (Covid-19) dan/ atau Dalam Rangka Menghadapi Ancaman yang Membahayakan Perekonomian Nasional dan/atau Stabilitas Sistem Keuangan Menjadi Undang-Undang (kutipan dari www.peraturan.bpk.go.id yang diakses pada tanggal 26 Desember 2020).

Oleh karena itu, pemerintah memberikan bantuan langsung tunai (BLT) bagi masyarakat yang terdampak dari virus Covid-19 yang bersumber dari Dana Desa atau disebut BLT-Dana Desa, untuk mengurangi beban masyarakat miskin atau kurang mampu akibat dampak Covid-19. BLT- Dana Desa adalah bantuan keuangan yang bersumber dari Dana Desa dan ditujukan bagi masyarakat miskin dan 
rentan yang kesulitan dalam memenuhi kebutuhan hidup sehari-hari terutama akibat dari wabah Covid-19.

Melihat dari sumber resmi bappenas.go.id bahwa Bantuan Langsung Tunai Dana Desa (BLT-Dana Desa) adalah bantuan uang kepada keluarga miskin di desa yang bersumber dari Dana Desa untuk mengurangi dampak buruk pandemi Covid-19. Adapun nilai BLT Dana Desa adalah Rp600.000,00,- setiap bulan untuk setiap keluarga miskin yang memenuhi kriteria dan diberikan selama 3 (tiga) bulan dan Rp300.000,00,- setiap bulan untuk tiga bulan berikutnya. Berdasarkan penjelasan diatas sehubungan dengan Bantuan Langsung Tunai Dana Desa (BLT-Dana Desa) di Desa Harapan Jaya Kecamatan Bunguran Tengah Kabupaten Natuna, masyarakat yang menerima Bantuan Langsung Tunai (BLT) Dana Desa di Desa Harapan Jaya Kecamatan Bunguran Tengah Kabupaten Natuna Tahun 2020 yakni dengan jumlah alokasi jumlah jiwa yang menerima sebanyak 225 Kepala Keluarga. Untuk lebih jelas data penerima Bantuan Langsung Tunai (BLT) Dana Desa di Desa Harapan Jaya Kecamatan Bunguran Tengah Kabupaten Natuna dapat dilihat pada Tabel di bawah ini.

Jumlah Penduduk Miskin Penerima BLT di Kecamatan Bunguran Tengah, Kabupaten Natuna 2020

\begin{tabular}{cc}
\hline Desa & Jumlah Alokasi \\
\hline Desa Harapan jaya & $225 \mathrm{KK}$ \\
Desa Tapau & $135 \mathrm{KK}$ \\
Desa Air Lengit & $143 \mathrm{kk}$ \\
\hline TOTAL & $\mathbf{5 0 3 ~ K K}$
\end{tabular}

Sumber: BPS Kabupaten Natuna, 2020

Bimo Walgito (2010) mengungkap bahwa persepsi merupakan suatu bentuk dari proses penginterpretasian serta pengorganisasian suatu stimulus yang telah diterima oleh organisme untuk menjadi sesuatu yang lebih berarti. Stimulus tersebut akan mendapatkan respon dari individu sesuai dengan perhatiannya, tentunya hal ini didasari oleh perhatian, pengalaman, perasaan, serta kemampuan berpikir individ yang menimbulkan perbedaan dalam penafsiran.

Menurut Mulyana, D (2014) dalam bukunya IImu Komunikasi Suatu pengantar, persepsi merupakan suatu proses yang secara internal untuk mengatur rangsangan yang dipeoleh dari lingkungan yang kemudian diproses dan mempengaruhi perilaku dimasa depan. Persepsi bersifat komunikasi, karena jika persepsi seorang individu salah maka tidak akan memungkinkan untuk berkomunikasi secara efektif. Hal ini yang memungkinkan bahwa semakin tinggi persamaan persepsi tiap individu, akibatnya kemungkinan besar akan terbentuk kelompok atau budaya identitas. Mulyana, D (2014) juga menyatakan bahwa ada tiga tahapan dalam proses persepsi yaitu sebagai berikut:

a. Sensasi, merupakan proses atau pengalaman dari alat indera dalam menerima stimulus. Atensi, merupakan pemrosesan informasi yang secara sadar yang didapatkan dari proses penginderaan, ingatan, maupun proses kognitif lainnya.

b. Interpretasi, merupakan tahapan paling penting dalam proses persepsi.

c. Interpretasi diperoleh melalui salah satu panca indera seseorang. Interpretasi adalah penafsiran atau penerjemahan stimulus yang diterima sehingga dapat memberikan arti.

Menurut Sudirman (2019) dalam jurnalnya yang berjudul Studi Persepsi Masyarakat terhadap Manfaat Bantuan Langsung Tunai yang telah dilakukan sebelum adanya pandemi di Desa Alo'o dan Desa Ogolugus Kecamatan Ampibabo 
Kabupaten Parigi Motoutong mengatakan bahwa Bantuan Langsung Tunai (BLT) sedikit banyaknya tentu memberikan manfaat bagi penerimanya, meskipun masyarakat menyadari bahwa bantuan ini bersifat sementara.

Peneliti juga melakukan wawancara terhadap salah satu staf kantor desa di Desa Harapan Jaya pada 23 Februari 2021 yang mengungkapkan bahwa BLT ini sangat membantu sekali masyarakat yang kurang mampu sekaligus meringankan beban masyarakat di masa pandemi covid19 untuk memenuhi kebutuhan sehari-hari dalam bentuk kebutuhan pokok.

\section{METODE PENELITIAN}

Desain penelitian ini adalah dengan menggunakan metode penelian deskriptif kualitatif. Penelitian kualitatif adalah penelitian dengan metode-metode untuk mengeksplorasi dan memahami makna yang tersimpan oleh sejumlah individu atau sekelompok orang dianggap berasal dari masalah sosial atau kemanusiaan (Creswell, 2015). Menurut Sugiyono (2014) metode penelitian deskriptif adalah metode untuk membandingkan satu variabel atau lebih sehingga peneliti dapat mengetahui nilai tanpa membuat perbandingan. Adapun sampel dalam penelitian ini berjumlah 4 orang yaitu seorang kepala Desa dan 3 orang warga penerima Bantuan Langsung Tunai (BLT).

\section{ANALISIS DATA}

Miles dan Huberman (dalam Sugiyono, 2013) mengemukakan bahwa aktivitas dalam analisis data kualitatif dilakukan secara interaktif dan berlangsung secara terus menerus sampai tuntas, sehingga datanya sudah jenuh. aktivitas dalam analisis data interaktif terbagi menjadi tiga, yaitu:

a. Mereduksi Data

Mereduksi data adalah langkah dalam memilah bagian-bagian penting serta merangkum hal pokok dari sebuah sumber data (Sugiyono, 2014).

b. Penyajian Data

Penyajian data dalam Penelitian kualitatif dilakukan dalam bentuk uraian singkat, bagan, ataupun tabel hubungan antar kategori atau sejenisnya.

c. Penarik Kesimpulan

Kesimpulan disini merupakan temuan baru dan belum pernah ada yang berupa kalimat yang diambil dari sebuah ide pemikiran. Temuan ini masih berupa remang-remang dan menjadi jelas setelah diteliti, (Sugiyono, 2014).

\section{HASIL DAN PEMBAHASAN}

Adanya program bantuan langsung tunai benar-benar memberikan manfaat kepada masyarakat yang kurang mampu di desa Harapan Jaya, Kabupaten Natuna. Terutama sekali membantu dalam meningkatkan kesejahteraan ekonomi masyarakat yang terdampak pandemi covid-19. Dalam merespon kerantanan akibat kebijakan yang diambil, Indonesia memiliki beragam bentuk perlindungan sosial. Perlindungan sosial yang dimaksudkan di sini adalah segala bentuk kebijakan dan intervensi pemerintah yang dilakukan untuk merespon beragam resiko, kerentanan dan kesengsaraan, baik yang bersifat fisik, ekonomi, maupun sosial, terutama yang dialami oleh mereka yang hidup dalam kemiskinan ( Suharto, E 2010).

Sehubungan dengan pernyataan diatas, hasil yang diperoleh dari wawancara bersama keempat Partisipan dalam penelitian ini, persepsi dari aspek pengetahuan (Kognitif) Partisipan sangat mendalam sekali pemahamanya terhadap BLT dan jenis-jenis bantuan sosial lainnya. Hal ini secara kebetulan Partisipan pertama, ES adalah seorang Kepala Desa di Desa Harapan Jaya Bunguran Tengah, Natuna. Bahwa BLT adalah Dana yang bersumber dari dana APBN (Anggaran Pendapatan dan Belanja Negara 
Indonesia). Yang di intruksikan oleh Presiden RI melalui Kementrian Desa, Kementrian Daerah Tertinggal kepada kepala Desa untuk memberikan Bantuan Langsung Tunai kepada setiap Warga yang ada di setiap desa. Kriteria dari penerima program seperti pada Partisipan kedua, ketiga, dan keempat secara pengetahuan melihat bahwa BLT adalah bantuan berupa sejumlah uang untuk membantu masyarakat ekonomi menengah kebawah. Dalam hal ini mereka tidak terlalu mengetahui dengan detail sumber dari program BLT, bagi Partisipan kedua, ketiga, dan keempat yang terpenting adalah manfaatnya bagi pemenuhan kebutuhan pokok. Persepsi dari keempat Partisipan dalam hal penyelenggaraan penyaluran Bantuan Langsung Tunai memiliki pengetahuan yang sama yakni dilaksanakan secara protokoler kesehatan. dengan mematuhi aturan antara lain; mengenakan masker, menjaga jarak, mencuci tangan dan mengikuti aturan antrian, karena pengambilan dengan secara langsung di Kantor desa.

Persepsi dari semua Partisipan dalam hal aspek Afektif (perasaan Partisipan) secara umum merasa senang dan dapat secara langsung memberi manfaat dalam memenuhi kebutuhan pokok, karena menerima langsung uang sebesar Rp600.000,00,- selama 3 bulan, yang selanjutnya Rp300.000,00,- setiap bulannya di tahun 2021 ini. Disamping kebutuhan pokok terutama sekali pada Partisipan kedua dan ketiga, juga memanfaatkan dananya pada kebutuhan lain. Bagi Partisipan keempat yang terpenting sekali adalah kebutuhan pokok, seperti beras dan gula. Partisipan pertama ES yang sekaligus sebagai Kepala Desa, merasa tidak begitu terlalu merasakan senang. Karena ada kecenderungan masyarakat lebih memanfaatkan kepada kebutuhan yang tidak semestinya, yaitu membeli barang-barang mewah. Sementara kebutuhan pokok lebih penting. Karena saat ini tahun 2021 kita sudah memasuki era normal baru. Jadi semestinya Bantuan Sosial lebih hendaknya bersifat pemberdayaan ekonomi kerakyatan. Karena pemanfaatan dimasyarakat kurang begitu efektif ada keputuhan yang pokok.

Kemudian tinjauan persepsi dari aspek Konatif atau Psikomotor (Perilaku) secara keseluruhan Partisipan sangat memahami dan sepakat mengikuti aturan dalam pelaksanaan pengambilan dana Bantuan Langsung Tunai di kantor Desa Harapan Jaya. Para Partisipan, terutama sekali Partisipan kedua, ketiga, dan keempat dalam menjemput/mengambil dana BLT dengan cara mematuhi aturan dalam Protokol Kesehatan, antara lain; mengenakan masker, menjaga jarak, mencuci tangan dan mengikuti aturan antrian, karena pengambilan dengan secara langsung ke Kantor desa. Seluruh Partisipan dalam penelitian ini menilai bahwa penyelenggaraan penyaluran Bantuan Langsung Tunai sudah berjalan sebagaimana mestinya, tepat pada sasaran, berjalan dengan baik tanpa ada kritik dan saran. Sehingga semua masyarakat yang sudah terdata di Desa Harapan Jaya Kecamatan Bunguran Tengah Kabupaten Natuna menerimanya dengan perasaan gembira.

\section{SIMPULAN}

Persepsi dari partisipan secara umum merasa senang dalam menerima Bantuan Langsung Tunai. Partisipan memahami dan sepakat mengikuti aturan dalam pelaksanaan pengambilan dana Bantuan Langsung Tunai. Serta partisipan juga menilai bahwa penyelenggaraan penyaluran Bantuan Langsung Tunai sudah berjalan sebagaimana mestinya yakni tepat pada sasaran serta sesuai dengan prosedur yang berlaku di masa pandemi covid-19. 


\section{SARAN}

Melalui penelitian ini diharapkan agar hasil yang diperoleh dapat menjadi bahan referensi bagi peneliti selanjutnya untuk dapat melanjutkan penelitian tentang persepsi masyarakat terhadap manfaat Bantuan Langsung Tunai, agar menjadi pengetahuan dan motivasi dalam kehidupan bagi mereka atau masyarakat yang pernah menerima.

\section{DAFTAR PUSTAKA}

Burhan, B. (2015). Metodologi penelitian kualitatif. Jakarta: Rajawali Pers.

Bappennas. Panduan Pendataan Bantuan Langsung Tunai Dana Desa (BLT-Dana Desa) Juni 2020. https://www.bappenas.go.id/id/beritadan-siaran-pers/panduan-pelaksanaanbantuan-langsung-tunai-dana-desa-bltdana-desa (diakses pada tanggal 26 Desember 2020 Pukul 09.00 WIB).

BPS Kabupaten

Natuna.

https://natunakab.bps.go.id. ( Diakses pada tanggal 26 November 2020 Pukul 13.30 WIB).

Creswell, J. W. (2015). Penelitian kualitatif \& desain riset. Yogyakarta: Pustaka Pelajar.

Humas Kemendes PDTT (2020). Setkab: BLT Dana Desa Diberikan untuk April Mei dan Juni. Diunduh pada tanggal 4 Januari $2021 \quad$ Dalam https://setkab.go.id/blt-dana-desadiberikan-untuk-april-mei-dan-juni/.

Hidayati, R. N. (2019). Analisis Persepsi Masyarakat Tentang Program Keluarga Harapan (PKH), Kualitas Pendampingan, dan Pengelolaan Dana Bantuan Di Desa Ngerco, Weru, Sukoharjo. Skripsi Thesis, Sanata Dharma University.

Isti, D. N, dkk. (2017). Persepsi dan partisipasi masyarakat terhadap pemanfaatan dana desa untuk pemberdayaan masyarakat di desa kertajaya kecamatan padalarang kabupaten bandung barat. Jurnal Pendidikan Luar Sekolah, 52- 62.

Kottler, P. (2013). Manajemen pemasaran, Edisi Ketiga belas. Jakarta: Erlangga.
Moleong. L. J. (2014). Metode penelitian kualitatif. Edisi Revisi. Bandung: PT Remaja Rosdakarya.

Mulyana, D. (2014). IImu komunikasi suatu pengantar. Bandung: PT Remaja Rosdakarya.

Poerwadarminto, W. J. S. (2014). Kamus umum bahasa indonesia. Jakarta: Balai Pustaka.

Rakhmat, J. (2015). Psikologi komunikasi. Bandung: PT Remaja Rosdakarya, Robbins, S. P. (2012). Perilaku organisasi, Jilid 1. Jakarta : PT. Prehallindo.

Salim, P., \& Salim, Y. (2012). Kamus bahasa indonesia kontemporer. Jakarta: Modern English Press.

Shadily, H. (2014). Sosiologi untuk masyarakat Indonesia. Jakarta: Bina Aksara. Walgito, B. (2010). Pengantar psikologi umum. Yogyakarta: CV Andi.

Sudirman. (2014). Studi persepsi masyarakat terhadap manfaat bantuan langsung tunai di desa alo'o dan desa ogolugus kecamatan ampibabo kabupaten parigi mouton (studi kasus desa pegunungan dan desa pesisir). Ejurnal Katalogis, 132-139.

Sugihartono, dkk. (2013). Psikologi pendidikan. Yogyakarta: UNY Pers. Sugiyono. (2014). Metode penelitian pendidikan pendekatan kuantitatif, kualitatif, dan $r \& d$. Bandung: Alfabeta.

Suharman. (2013). Psikologi kognitif. Surabaya: Srikandi.

Suharto, E. (2010). Kemiskinan dan Perlindungan Sosial di Indonesia. Bandung: Alfabeta.

Sunaryo. (2013). Psikologi untuk pendidikan. Jakarta: EGC.

Sutisna. (2013). Perilaku konsumen dan komunikasi pemasaran. Bandung: PT Remaja Rosdakarya.

Supriyanto, R.W, dkk. (2014). Perlindungan Sosial di Indonesia : Tantangan dan Arah Kedepan. Bappenas: Jakarta.

Thoha, M. (2013). Perilaku organisasi konsep dasar dan implikasinya. Jakarta: PT. Raja Grafindo.

Walgito, B. (2010). Pengantar psikologi umum. Yogyakarta: CV Andi. www.peraturan.bpk.go.id diunduh pada tanggal 23 Desember 2020 